\title{
College Research Training Co-ordinators
}

In a previous article the Chairman of the Research Committee (Freeman, Psychiatric Bulletin, 1992, 16, 57-59) elaborated a proposal for the establishment of a network of College Research Training Coordinators. The purpose of the network would be to provide practical assistance and supervision, particularly for trainees engaging in research for the first time. It will be run under the auspices of the Research Committee and nominations are now sought for research training coordinators from among the membership of the College. University and post-graduate departments will be approached directly but the Research Committee would be pleased to hear of any members of the College who would like to become involved. Detailed information describing the objectives of the network can be obtained by writing to the Education Department at the College.

Psychiatric Bulletin (1993), 17, 378-379

\section{Obituaries}

Editor: Henry R. Rollin

Sigrid Herold, formerly Senior Registrar, Charing Cross Higher Training Scheme in Psychiatry, London

Sigrid Herold died, aged 39 years, at home in Ealing on 19 July 1992 from cholangiocarcinoma.

She graduated in biochemistry and medicine from the University of Tuebingen, West Germany, and initially trained in neurology before settling in the UK after completing a visiting fellowship in neurology based at the MRC Cyclotron Unit at the Hammersmith Hospital in 1985. She decided to specialise in psychiatry and did general training at the Maudsley Hospital, subsequently gaining membership of the Royal College of Psychiatrists in 1990. She took up senior registrar posts at St Bernard's Wing, Ealing Hospital, in rehabilitation and forensic psychiatry.

Throughout her training Sigrid maintained an active interest in research, making a valuable contribution to the field of positron emission tomography and specialising in its application to autism, schizophrenia and cerebrovascular disease. Most recently her research involvement also encompassed psychosocial and epidemiological aspects of schizophrenia. She published widely and had the promise of an excellent academic career ahead of her. Her critical mind and practical research abilities were enhanced by the striking clarity and enthusiasm with which she communicated. She will undoubtedly be remembered by the many psychiatrists and cohorts of medical students who worked with her for these qualities as well as for her modesty, warmth and her vibrant sense of humour. She believed strongly in the value of good teaching within medicine and facilitated a high standard of post-graduate psychiatric training at St Bernard's Wing.

Outside of work she delighted in being with her family. Her openness to affection and generous nature were always evident. Her keen interest in art and social issues and her enviable cooking ability gave rise to enjoyable hospitality for her many friends. She was able to marry a busy and fulfilling work and home life and through her experience she offered particular support to other women doctors who knew her.

In facing her terminal illness her natural positive thinking and courage were prominent. She is survived by her husband, Terry Jones, and her 4-year-old daughter Julia.

Jo BOWEN

Eugene Patrick Jones, formerly Medical Superintendent, Gransha Hospital, Londonderry, Northern Ireland

Eugene Jones died unexpectedly in Down Hospital, Downpatrick, on 25 December 1992.

Dr Jones graduated in medicine at Queen's University, Belfast, in 1953. He did his intern year at the Mater Hospital and then commenced his 
psychiatric training in Downshire Hospital. He obtained the DPM in 1957 and MRCPI in 1962 . He passed the MRCPsych in 1972, and was elected FRCPI in 1978 and FRCPsych in 1985.

He was appointed Consultant Psychiatrist to Gransha Hospital in 1964, succeeding Dr Dawson as Medical Superintendent in 1971. He had a special interest in general psychiatry, child psychiatry and forensic psychiatry. He had wide experience in management and from 1977-1979 was Chairman of Medical Staff/Medical Executive Committees at Altnagelvin Area Hospital.

After his retirement in 1987 he and his wife moved to live in Saintfield, County Down.

Dr Jones is survived by his wife Kathleen and two sons, John and Peter, both of whom are in general practice in England, and to them and the family circle we extend our deepest sympathy.

DeRmot NugENT

Chris WardLE, formerly Director, Iddesleigh House Clinic and Dryden Clinic, Exeter; Consultant Child \& Adolescent Psychiatrist, Royal Devon \& Exeter Hospital

Christopher John Wardle died in September 1992 , aged 64. He was born in Hampstead, attended Gillingham Grammar School and Bishop Wordsworth School, Salisbury, and then commenced his medical studies at Kings College Hospital. Winning the White Prize in Psychological Medicine was an early indication of his specialty interest. He graduated in 1951 and subsequently undertook postgraduate training at the Institute of Psychiatry, gaining the DPM in 1959 and MD, Lond the following year. He was elected MRCPsych in 1971 and proceeded to the Fellowship in 1978. He held a commission in the Royal Navy and was awarded the Korean Service Medal and the United Nations Medal.

His lifetime professional work lay in establishing and developing the Child \& Adolescent Psychiatric Services in Exeter, with clinics in other Devonshire towns. He was happiest in active clinical work, especially in his lively Residential Centre in the Wonford Hospital, where he maintained a totally child-centred milieu which was always great fun and indeed had a certain magic. From his own enjoyment of mischief and play, he made immediate contact with children. This emerged from his personality, although he also deliberately fostered it. His chapter on running such a unit appeared in the textbook on Residential Psychiatric Treatment for Children, edited by Barker in 1974.

Wardle's clinical approach had been based on a careful study of the activity group play of S.R. Slavson. In some ways he anticipated many of the strategies of the family therapists, e.g. paradox, by-passing resistance through magic, tricks and laughter.

While always exercising the highest standards of his profession and expecting the same of his colleagues and staff, Wardle eschewed formality and humbug, and sought to get immediately to the nub of the matter in hand. Yet, as colleagues in the College know, he undertook committee work with dedication and verve, and served on his Section's Executive Committee and the Nursing Sub-Committee. He published a number of papers on social factors in psychiatry and on conduct disorder, and more recently, his excellent review articles on the historical development of child and adolescent psychiatric services revealed what a thorough knowledge he possessed of his specialty. He carried it lightly.

When his five children were reared, he retired from active practice, and with his wife, Mary, devoted himself to quintessential West country interests on Inner Clyst Farm-singing, mumming, cidermaking, bee-keeping and ponies.

Three months before his untimely death, as a keynote speaker, he delighted an ACPP Conference in the West of Ireland. This was followed by adventures on the Aran Islands and the Burren where he pursued another interest - iron age archeology.

As he left he said, with his infectious chuckle, "This is probably my swan song." Sadly it was.

anthony G. Carroll

It has been decided that self-written obituaries would be welcome; they should be about 250 words in length and, if possible, accompanied by a reasonably recent good quality photograph.

\section{The deaths of the following have also been reported:}

Geoffrey Arthur Goding, retired, 24 Walpole Street, Kew, Victoria 3101, Australia.

IDA Gonsalves, formerly Consultant Psychiatrist, Llanfrechfa Grange Hospital, Cwmbran, Gwent, Wales NP4 2YN.

Vassilis Nicholas Minhas, Consultant Psychiatrist, 24 Baywater Place, Rotherhithe, London SE16 IND.

MOHSEN SOBhy NAGUIB, Senior Lecturer, St Mary's Hospital Medical School and St Charles' Hospital, Exmoor Street, London W10.

RAmon Francis Norris, Consultant Psychiatrist, Highcroft Hospital, Erdington, Birmingham B23 6AS.

David Shaw, formerly Consultant Psychiatrist, 5 All Saints Road, Sutton, Surrey.

William Alistair Stewart, Associate Specialist, Ross Clinic, Cornhill Road, Aberdeen, Scotland AB9 2ZX.

Frank Winston, retired, 6010 California Circle, Apt. No. 311, Rockville, MD 20852, USA. 